\title{
Evaluation of Major Minerals and Trace Elements in Wild and Domesticated Edible Herbs Traditionally Used in the Mediterranean Area
}

\author{
Costanza Ceccanti ${ }^{1}$ (D) Andrea Brizzi ${ }^{1} \cdot$ Marco Landi $^{1,2} \cdot$ Luca Incrocci $^{1} \cdot$ Alberto Pardossi $^{1,2} \cdot$ Lucia Guidi $^{1,2}$
}

Received: 9 September 2020 / Accepted: 28 October 2020 / Published online: 5 November 2020

(C) The Author(s) 2020

\begin{abstract}
The human diet is characterized by the intake of major minerals ( $\mathrm{Na}, \mathrm{K}, \mathrm{Ca}, \mathrm{Mg}, \mathrm{P}, \mathrm{N})$ and trace elements $(\mathrm{Zn}, \mathrm{Mn}, \mathrm{Se}, \mathrm{Cu}, \mathrm{Fe}$, $\mathrm{Co}, \mathrm{I}, \mathrm{Cr}, \mathrm{F}, \mathrm{Pb}, \mathrm{Cd}$ ) for their key role in many metabolic functions. Nowadays, the research of sources able to improve their intake is in continuous evolution, especially in the undeveloped countries. In this sense, wild edible herbs, commonly used since ancient times, can represent a good alternative to improve the daily human intake of minerals. In this study, four wild edible species, Rumex acetosa, Picris hieracioides, Cichorium intybus, and Plantago coronopus, were analyzed for their content in Na, $\mathrm{K}, \mathrm{Ca}, \mathrm{Mg}, \mathrm{Cu}, \mathrm{Mn}, \mathrm{Fe}$, and $\mathrm{Zn}$ and, besides, three domestications (named "soilless," pot, and open field) were evaluated in the analyzed species in the prospective of their commercialization as valuable sources of minerals in the human diet. Nitrate and oxalate contents were also evaluated, given their negative impact on human health. Results unveil that open field domestication allowed the plants to maintain the content of major minerals similar to those measured in wild plants, especially in $C$. intybus and $P$. hieracioides. The trace elements $\mathrm{Cu}, \mathrm{Mn}, \mathrm{Fe}$, and $\mathrm{Zn}$ were not recorded at high content irrespectively to the wild collection or domestications. Finally, plants grown in the open field also accounted for a high oxalate and nitrate content, especially in $R$. acetosa. Further researches should be aimed at decreasing the oxalate and nitrate content in the domesticated species and to promote the commercialization of the domesticated species.
\end{abstract}

Keywords Human diet · Major minerals · Trace elements · Wild edible herbs $\cdot$ Domestication

\section{Introduction}

The quantification of major minerals for human diet (sodium, potassium, calcium, magnesium, phosphorus) and trace elements (zinc, manganese, selenium, copper, iron, cobalt, iodine, chromium, fluorine, lead, cadmium) in leaves from different wild edible herbs, the research about their roles in various human metabolic processes, and, therefore, their impact on human health have an increased interest due to mineral and trace element deficiencies in the human diet [1]. In fact, these micronutrients are largely present in wild species used as dietary item as well as ingredient in traditional recipes of the Mediterranean area [2].

Costanza Ceccanti

c.ceccanti3@studenti.unipi.it

1 Department of Agriculture, Food and Environment, University of Pisa, Pisa, Italy

2 Interdepartmental Research Center Nutrafood "Nutraceuticals and Food for Health", University of Pisa, Pisa, Italy
Nowadays, a serious global problem in the human diet has become trace element deficiencies, especially in areas where the diet lacks variety [3]. For example, iron has been recognized as the most diffuse form of trace element affliction, while the prevalence of zinc deficiency is also thought to be relevant [1]. Iron deficiency and low hemoglobin can cause iron deficiency anemia, infectious disorders, and hemoglobinopathies. Dietary intake of iron is low in populations consuming monotonous plant-based diet [4]. The most important strategy to decrease trace element deficiencies has been applied to address dietary modifications and variations, focusing on increasing the amount of trace elements consumed in the diet and, simultaneously, maintaining a balanced intake of minerals [3].

Currently, the modernization and the globalization in agriculture have resulted in simplification of diets with the imposition of few staple crops [5]. For this reason, the integration of wild edible herbs to human diets has been promoted; an increasing consensus that wild species could significantly contribute in alleviating malnutrition and hunger and, consequently, neglected crops and wild edible herbs are receiving 
renewed attention, with the identification of them as convenient sources of income and vehicles for improved nutrition [1]. Little researches are already available about mineral and trace element composition in domesticated and wild edible herbs; this is probably because the uptake of these components strongly depends on botanical and genetic characteristics, besides different environmental and agronomic conditions [6-9]. For example, Disciglio et al. [6] showed that wild rocket (Diplotaxis tenuifolia (L.) DC.) contained higher value of sodium, potassium, and fluoride than cultivated rocket and Turan et al. [7] reported that 26 wild edible species contained higher value of $\mathrm{N}, \mathrm{K}, \mathrm{Ca}$, and $\mathrm{Mg}$ than cultivated lettuce, spinach, or cabbage.

Besides their excellent major mineral and trace element amounts when compared to common leafy vegetables, wild edible herbs are often abundant in toxic compounds and they could not be used in the human diet or not eaten in large quantity. In fact, some studies reported a high content of oxalate and nitrate and other toxic compounds in Rumex acetosa L., Sanguisorba minor Scop., Portulaca oleracea L., and other wild edible species [10-12].

For all these reasons, a preliminary assessment of different domestications of the wild edible herbs should be investigated to promote the higher amount of major minerals and trace elements able to satisfy human diet requirement and to reduce possible high content of unhealthy elements such as nitrate or oxalate. The recognition of domestications able to obtain an efficient reproducibility of plants with a balanced micronutrient content represents a first step toward the large-scale commercialization of new edible species and, therefore, the variability of the human diet.

The aim of this study was to increase the knowledge about major minerals and trace elements in plants of four edible species, Cichorium intybus, Rumex acetosa, Picris hieracioides L., and Plantago coronopus L. (commonly used since ancient times during famine periods in mixtures, boiled or in soups in the Mediterranean area and already described in a previous study [2]) collected in the wild or subjected to three domestications (namely "soilless" (SS), pot (P), and open field $(\mathrm{OF})$ ). In particular, this preliminary investigation aimed at evaluating the domestications able to preserve micronutrient content, this in order to compensate for lack of major minerals and trace elements in the human diet and favoring the marketability of these "rediscovered" species.

\section{Materials and Methods}

\section{Plant Material, Growing Conditions, and Experimental Design}

Ten seedlings of $C$. intybus, $R$. acetosa, $P$. hieracioides, and $P$. coronopus were gathered in the wild (W) in the Pisa area as reported by Ceccanti et al. [13]. Furthermore, seedlings of the same species were cultivated using three different kinds of domestication: "soilless" (SS), pot (P), and open field (OF) systems. Details of different domestications were reported in a previous study [13].

Before the flowering, leaves of the domesticated and wild species were collected with a cut up above the substrate level, taking care to collect the youngest leaves of the basal rosette, botanical characteristic of all the examined species. Leaves of each species from wild collection or each different domestication were randomly selected, pooled, weighed, and oven-dried at $65{ }^{\circ} \mathrm{C}$ to constant weight and the dry weights were then noted, and percentage of dry matter (DM) was calculated. Dry samples were used for the chemical analyses that were carried out in triplicate.

\section{Mineral and Trace Element Analysis}

A total of $200 \mathrm{mg}$ dried samples were powdered and mineralized $\left(90\right.$ min at $220{ }^{\circ} \mathrm{C}$ ) using a solution of $\mathrm{HNO}_{3}: \mathrm{HClO}_{4}$ $(2.5: 1 ; \mathrm{v}: \mathrm{v})$. Minerals (sodium, potassium, calcium, and magnesium) and some trace elements (copper, iron, manganese, and zinc) were determined using an atomic absorption spectrometer (Varian 240FS AA, Sidney, Australia). Data are expressed as mg mineral per $g$ fresh weight $(\mathrm{FW})$ or $\mu \mathrm{g}$ trace element per g FW.

\section{Nitrate and Oxalate Analysis}

Nitrate $\left(\mathrm{NO}_{3}{ }^{-1}\right)$ and oxalate $\left(\mathrm{C}_{2} \mathrm{O}_{4}{ }^{-2}\right)$ concentrations were determined using an IonPac AG4A guard column and an IonPac AS4A analytical column of an ion exchange chromatograph (Dionex DX120, Dionex Corporation, Sunnyvale, CA, USA) with a conductivity detector as reported by D'Imperio et al. [14], with minor modifications. The eluent was constituted by $1.8 \mathrm{mM} \mathrm{Na}_{2} \mathrm{CO}_{3} / 1.7 \mathrm{mM} \mathrm{NaHCO}_{3}$ with a flow rate of $2 \mathrm{~mL} /$ $\mathrm{min}$. The suppressor was an anion micromembrane suppressor (the AMMS-II) and the regenerant was constituted by $50 \mathrm{mN}$ $\mathrm{H}_{2} \mathrm{SO}_{4}$ with a flow rate of 3-5 $\mathrm{mL} / \mathrm{min}$. The column storage solution was constituted by $100 \mathrm{mM} \mathrm{NaOH}$ and the background conductivity was 15-20 $\mu$ S. Standard solutions of $5 \mathrm{ppm} \mathrm{NaNO}_{3}$ (Sigma Aldrich, Saint Louis, USA) and of $10 \mathrm{ppm} \mathrm{CaC}_{2} \mathrm{O}_{4}$ (Sigma Aldrich, Saint Louis, USA) were injected as reference solutions. The extraction was obtained by adding dried and powdered material $(0.2 \mathrm{~g})$ to $25 \mathrm{~mL}$ of Milli-Q water and incubating samples in a water bath, kept in agitation for $1 \mathrm{~h}$ at $60^{\circ} \mathrm{C}$. Data are expressed as mg nitrate or oxalate per $\mathrm{g} \mathrm{FW}$.

\section{Statistical Analysis}

Data were subjected to a one-way ANOVA and statistical differences between wild and domesticated species under 
investigation were calculated by the least significant difference (LSD; $P=0.05$ ) with GraphPad Software (GraphPad, La Jolla, USA). Data are expressed as mean \pm standard deviation $( \pm \mathrm{SD})$ of three replicates.

\section{Results and Discussion}

\section{Major Minerals and Trace Elements}

Table 1 reports the results of dry matter of the species under investigation harvested in wild conditions or after domestication with three agronomical practices.

DM accumulation was significantly higher in all the species collected as wild, even though $P$. coronopus and C. intybus DM was similar to plants gathered in the wild once domesticated in OF. The higher amount of DM measured in wild plants may be due to the advantage of nutrient solution supply in both SS and P domestications, which led plants to have a higher moisture content [15]. Our findings agree with results of Nicola et al. [15] who reported that rocket grown in a soil system had $41.5 \%$ higher DM content than plants grown in a soilless system. Moreover, our data are close to dry matter data reported by other researches (in a range of 7-29\%) for different species of wild leafy vegetables $[16,17]$.

The concentrations of main major minerals $\mathrm{Na}, \mathrm{K}, \mathrm{Ca}$, and $\mathrm{Mg}$ useful for human diet were analyzed in the four examined wild and domesticated edible species (Table 2). Significative differences among wild and domesticated plants were observed in all the species, except for the $\mathrm{Na}$ amount which was similar in both wild and domesticated plants in P. coronopus. In most of the cases, the OF domestication produced plants with foliar mineral contents similar to those measured in leaves of wild species. Some species maintained the mineral content of the major minerals during the SS domestication, e.g., the $\mathrm{Na}$ amount in $P$. hieracioides, or during the $\mathrm{P}$ domestication, such as the $\mathrm{Na}$ amount in $C$. intybus.
The presence of minerals in the human diet is essential for the metabolism and the human health. For instance, $\mathrm{K}$ is fundamental in the maintenance of total body fluid volume and in various metabolic functions such as the protection of muscles and healthy effects on nerve activity $[18,19]$. Potassium deficiency has been associated with hypertension as well as cardiovascular disease and stroke and the wild and OFdomesticated edible species under investigation reported $\mathrm{K}$ content similar to spinach cabbage and parsley (approximately $550 \mathrm{mg} 100 \mathrm{~g}^{-1} \mathrm{FW}$ ), already considered as sources of this macronutrient [19]. The comparison of the examined species with common vegetables such as spinach, cabbage and parsley, and lettuce is necessary because the purpose of the study is to propose new edible species to enhance the major mineral and trace element intake in the human diet nowadays provided by other widely cultivated leafy vegetables.

$\mathrm{Na}$ is linked with $\mathrm{K}$ because of the competition of these two ions in human diet; therefore, an increasing intake of potassium in hypertensive subjects is recommended [20]. In fact, a reduced intake of $\mathrm{Na}$ is suggested because of its role in the hypertension disease [21]. The analyzed species showed higher level of $\mathrm{Na}$ than that found in common lettuce [22], even though, in some cases, the domestication resulted in decreasing the leaf $\mathrm{Na}$ level such as all the three domestications in $R$. acetosa, the OF domestication in P. hieracioides, and the $\mathrm{OF}$ and SS domestications in $C$. intybus.

Calcium is essential for the skeletal system and Ca deficiency leads to osteoporosis, which is a public health problem, especially in undeveloped countries [23]. The diet of the developed countries is characterized by dairy products rich in calcium (e.g., cheese, butter, yoghurt), but the cost of these foods is not affordable for most people living in undeveloped countries who, as a consequence, suffer of skeletal system diseases [23]. Accordingly, the species under investigation, especially those collected in the wild, might represent a reasonable source of calcium in the human diet, even though they are not able to improve the dairy calcium dose when compared with common vegetables such as lettuce and rocket [24, 25].
Table 1 Influence of wild collection (W) or domestication (SS: "soilless"; P: pot; and OF: open field) on leaf dry matter (DM) of Rumex acetosa, Picris hieracioides, Cichorium intybus, and Plantago coronopus

\begin{tabular}{|c|c|c|c|c|c|}
\hline \multicolumn{6}{|l|}{ Leaf DM (\%) } \\
\hline \multirow[t]{2}{*}{ Species } & \multicolumn{4}{|c|}{ Wild collection or cultivation technique } & \multirow[b]{2}{*}{ Significance } \\
\hline & SS & $\mathrm{P}$ & OF & W & \\
\hline Rumex acetosa & $7.0 \pm 0.6 \mathrm{~b}$ & $5.5 \pm 0.7 \mathrm{c}$ & $10.9 \pm 0.3 \mathrm{a}$ & $10.3 \pm 0.4 \mathrm{a}$ & $* * *$ \\
\hline Picris hieracioides & $9.5 \pm 1.3 \mathrm{c}$ & $7.8 \pm 0.5 \mathrm{~d}$ & $12.5 \pm 0.2 b$ & $14.4 \pm 0.5 \mathrm{a}$ & $* * *$ \\
\hline Cichorium intybus & $8.8 \pm 0.6 \mathrm{c}$ & $9.3 \pm 0.3 b c$ & $14.1 \pm 0.8 \mathrm{a}$ & $10.3 \pm 1.0 \mathrm{~b}$ & $* * *$ \\
\hline Plantago coronopus & $7.8 \pm 1.0 \mathrm{c}$ & $5.8 \pm 0.1 \mathrm{~d}$ & $10.9 \pm 0.4 \mathrm{a}$ & $9.5 \pm 0.4 b$ & $* * *$ \\
\hline
\end{tabular}

Each value is the mean $( \pm \mathrm{SD})$ of three replicates; values followed by the same letter within a row are not significantly different $(P<0.05)$. In the last column, the significance of the $F$ ratio following one-way ANOVA test is reported. $* * * P<0.001$ 
Table 2 Major mineral composition of Rumex acetosa, Picris hieracioides, Cichorium intybus, and Plantago coronopus leaves wild collected (W) and domesticated according to three different domestications: "soilless" (SS), pot (P), and organic field (OF)

\begin{tabular}{|c|c|c|c|c|c|}
\hline \multirow[t]{2}{*}{ Species } & \multirow{2}{*}{$\begin{array}{l}\text { Wild collection } \\
\text { or cultivation } \\
\text { technique }\end{array}$} & \multicolumn{4}{|c|}{ Minerals $\left(\mathrm{mg} \mathrm{g}^{-1} \mathrm{FW}\right)$} \\
\hline & & $\mathrm{Na}$ & $\mathrm{K}$ & $\mathrm{Ca}$ & $\mathrm{Mg}$ \\
\hline \multirow[t]{4}{*}{ Rumex acetosa } & SS & $0.22 \pm 0.03 b$ & $3.03 \pm 0.22 b c$ & $0.47 \pm 0.06 \mathrm{c}$ & $0.45 \pm 0.03 b$ \\
\hline & $\mathrm{P}$ & $0.11 \pm 0.08 \mathrm{c}$ & $2.82 \pm 0.39 \mathrm{c}$ & $0.72 \pm 0.01 b$ & $0.51 \pm 0.04 \mathrm{~b}$ \\
\hline & $\mathrm{OF}$ & $0.13 \pm 0.02 \mathrm{c}$ & $5.76 \pm 0.43 \mathrm{a}$ & $1.72 \pm 0.12 \mathrm{a}$ & $1.20 \pm 0.06 \mathrm{a}$ \\
\hline & $\mathrm{W}$ & $0.60 \pm 0.04 \mathrm{a}$ & $3.35 \pm 0.10 \mathrm{~b}$ & $0.64 \pm 0.02 b$ & $0.21 \pm 0.01 \mathrm{c}$ \\
\hline Significance & & $* * *$ & $* * *$ & $* * *$ & $* * *$ \\
\hline \multirow[t]{4}{*}{ Picris hieracioides } & SS & $1.36 \pm 0.12 \mathrm{a}$ & $2.90 \pm 0.30 \mathrm{~d}$ & $0.98 \pm 0.07 \mathrm{~d}$ & $0.14 \pm 0.03 b$ \\
\hline & $\mathrm{P}$ & $1.30 \pm 0.04 \mathrm{a}$ & $3.62 \pm 0.07 \mathrm{c}$ & $1.50 \pm 0.07 \mathrm{c}$ & $0.06 \pm 0.03 \mathrm{c}$ \\
\hline & $\mathrm{OF}$ & $0.74 \pm 0.11 \mathrm{c}$ & $7.32 \pm 0.65 \mathrm{a}$ & $3.57 \pm 0.08 b$ & $0.54 \pm 0.01 \mathrm{a}$ \\
\hline & W & $0.95 \pm 0.04 b$ & $6.02 \pm 0.06 \mathrm{~b}$ & $4.73 \pm 0.65 \mathrm{a}$ & $0.08 \pm 0.05 \mathrm{c}$ \\
\hline Significance & & $* * *$ & $* * *$ & $* * *$ & $* * *$ \\
\hline \multirow[t]{4}{*}{ Cichorium intybus } & SS & $0.94 \pm 0.07 b$ & $4.62 \pm 0.36 b$ & $1.16 \pm 0.07 \mathrm{~d}$ & $0.18 \pm 0.02 c$ \\
\hline & $\mathrm{P}$ & $1.58 \pm 0.10 \mathrm{a}$ & $3.70 \pm 0.43 c$ & $1.52 \pm 0.12 b$ & $0.33 \pm 0.02 b$ \\
\hline & $\mathrm{OF}$ & $0.41 \pm 0.05 \mathrm{c}$ & $10.95 \pm 0.65 a$ & $2.53 \pm 0.22 \mathrm{a}$ & $0.51 \pm<0.01 \mathrm{a}$ \\
\hline & W & $1.59 \pm 0.25 \mathrm{a}$ & $4.05 \pm 0.24 b c$ & $1.32 \pm 0.10 \mathrm{c}$ & $0.10 \pm 0.01 \mathrm{~d}$ \\
\hline Significance & & $* * *$ & $* * *$ & $* * *$ & $* * *$ \\
\hline \multirow[t]{4}{*}{ Plantago coronopus } & SS & $1.67 \pm 0.32$ & $2.82 \pm 0.54 b$ & $1.60 \pm 0.26 b$ & $0.14 \pm 0.07 b c$ \\
\hline & $\mathrm{P}$ & $1.30 \pm 0.02$ & $1.87 \pm 0.20 \mathrm{c}$ & $1.40 \pm 0.07 \mathrm{bc}$ & $0.18 \pm 0.01 b$ \\
\hline & $\mathrm{OF}$ & $1.72 \pm 0.01$ & $3.61 \pm 0.19 \mathrm{a}$ & $3.71 \pm 0.07 \mathrm{a}$ & $0.30 \pm 0.01 \mathrm{a}$ \\
\hline & $\mathrm{W}$ & $1.27 \pm 0.26$ & $2.46 \pm 0.27 b$ & $1.23 \pm 0.11 \mathrm{c}$ & $0.08 \pm 0.05 \mathrm{c}$ \\
\hline Significance & & $n s$ & $* *$ & $* * *$ & $* *$ \\
\hline
\end{tabular}

Each value is the mean $( \pm \mathrm{SD})$ of three replicates. Means within each column, considering each species separately, keyed with a different letter are significantly different at $P=0.05$ and following, for each major mineral, one-way ANOVA with the different kinds of collection (SS; P; OF; W) as variability factor. For each species in the last row, the significance level of the $F$ ratio following one-way ANOVA test is reported. $* * * P<0.001 ; * * P<$ $0.01 ; n s$ :not significant $(P>0.05)$

Magnesium is a fundamental constituent of bones and teeth; it is a cofactor for many enzymes in the human body such as ATP-dependent kinase and it affects permeability of membranes and neuromuscular transmission [26]. This mineral is a $\mathrm{Ca}$ antagonist on vascular smooth muscle tone and on post-receptor insulin signaling [27]. Nevertheless, our findings resulted lower than those found in wild and domesticated plants by Disciglio et al. [6], but, notably, higher than those found in lettuce cultivated using a soilless system by Fallovo et al. [24].

Table 3 reports the level of some trace elements in the species under investigation and the differences among wild and domesticated species. Leaves of the wild species showed the significantly highest $\mathrm{Cu}$ content, except for $C$. intybus in which the highest amount was recorded in OF-domesticated plants. Mn content was significantly higher in leaves of OFdomesticated plants than in wild plants. The only exception was represented by $R$. acetosa leaves in which Mn was similar in both P-domesticated and wild plants. Leaves of $P$. hieracioides reported the significative highest Fe content in leaves collected as wild between all analyzed domesticated samples in all species and leaves from C. intybus did not report significative differences between wild and domesticated plants. Furthermore, $R$. acetosa and $C$. intybus accumulated a higher level of $\mathrm{Zn}$ in leaves of SS- and P-domesticated plants when compared to wild-harvested plants. $P$. hieracioides reported similar $\mathrm{Zn}$ amount in wild plants and P-domesticated plants, while $P$. coronopus plants accounted for higher amount of $\mathrm{Zn}$ in SS-domesticated plants than in leaves collected from wild plants.

$\mathrm{Cu}, \mathrm{Mn}, \mathrm{Fe}$, and $\mathrm{Zn}$ are considered as among the most important bivalent ions involved in human health and development [5]. Mn is a pivotal cofactor for many enzymes including the antioxidant enzyme Mn-superoxidase dismutase and the pyruvate carboxylase, as well as hydrolases, transferases, and kinases; some of them are important in the metabolism of macronutrients, in the bone and cartilage development [28]. Dietary Mn intake is decreasing in the developed countries because of the shifting of the human dietary intake to processed, fat, and sugary foods [28] and, therefore, the 
Table 3 Trace element composition of Rumex acetosa, Picris hieracioides, Cichorium intybus, and Plantago coronopus leaves wild collected (W) and domesticated according to three different domestications: "soilless" (SS), pot (P), and open field (OF)

\begin{tabular}{|c|c|c|c|c|c|}
\hline \multirow[t]{2}{*}{ Species } & \multirow{2}{*}{$\begin{array}{l}\text { Wild collection } \\
\text { or cultivation } \\
\text { technique }\end{array}$} & \multicolumn{4}{|c|}{ Trace elements ( $\left.\mu \mathrm{g} \mathrm{g}^{-1} \mathrm{FW}\right)$} \\
\hline & & $\mathrm{Cu}$ & Mn & $\mathrm{Fe}$ & $\mathrm{Zn}$ \\
\hline \multirow[t]{4}{*}{ Rumex acetosa } & SS & $1.91 \pm 0.08 b$ & $7.95 \pm 0.52 b$ & $15.76 \pm 2.30 \mathrm{c}$ & $8.93 \pm 0.56 a$ \\
\hline & $\mathrm{P}$ & $1.55 \pm 0.03 \mathrm{c}$ & $16.74 \pm 3.72 \mathrm{a}$ & $30.22 \pm 6.69 \mathrm{a}$ & $9.64 \pm 0.93 \mathrm{a}$ \\
\hline & OF & $1.96 \pm 0.15 b$ & $10.28 \pm 0.18 b$ & $22.17 \pm 2.66 b$ & $8.11 \pm 1.03 b$ \\
\hline & $\mathrm{W}$ & $2.86 \pm 0.07 \mathrm{a}$ & $14.96 \pm 0.92 \mathrm{a}$ & $22.73 \pm 1.46 b$ & $6.85 \pm 0.19 c$ \\
\hline Significance & & $* * *$ & $* *$ & $*$ & $* *$ \\
\hline \multirow[t]{4}{*}{ Picris hieracioides } & SS & $1.95 \pm 0.11 \mathrm{c}$ & $9.75 \pm 0.72 \mathrm{c}$ & $20.22 \pm 0.71 \mathrm{c}$ & $8.77 \pm 0.60 \mathrm{~b}$ \\
\hline & $\mathrm{P}$ & $1.38 \pm 0.21 \mathrm{~d}$ & $8.20 \pm 0.69 d$ & $15.35 \pm 0.62 c$ & $9.90 \pm 1.35 \mathrm{ab}$ \\
\hline & $\mathrm{OF}$ & $3.45 \pm 0.19 b$ & $16.71 \pm 1.05 \mathrm{a}$ & $39.21 \pm 5.85 b$ & $7.20 \pm 0.02 \mathrm{c}$ \\
\hline & $\mathrm{W}$ & $4.68 \pm 0.58 \mathrm{a}$ & $11.61 \pm 0.36 b$ & $124.86 \pm 12.82 \mathrm{a}$ & $10.30 \pm 0.50 \mathrm{a}$ \\
\hline Significance & & $* * *$ & $* * *$ & $* * *$ & $* *$ \\
\hline \multirow[t]{4}{*}{ Cichorium intybus } & SS & $2.52 \pm 0.11 \mathrm{c}$ & $10.21 \pm 0.21 \mathrm{c}$ & $26.05 \pm 1.75$ & $11.09 \pm 0.35 \mathrm{a}$ \\
\hline & $\mathrm{P}$ & $0.88 \pm 0.03 \mathrm{~d}$ & $12.51 \pm 1.30 \mathrm{~b}$ & $27.95 \pm 12.18$ & $10.95 \pm 0.96 \mathrm{a}$ \\
\hline & $\mathrm{OF}$ & $4.16 \pm 0.28 \mathrm{a}$ & $18.19 \pm 0.28 \mathrm{a}$ & $39.74 \pm 1.89$ & $9.72 \pm 1.32 b$ \\
\hline & $\mathrm{W}$ & $2.86 \pm 0.23 b$ & $7.07 \pm 0.46 \mathrm{~d}$ & $24.62 \pm 1.74$ & $6.39 \pm 0.57 \mathrm{c}$ \\
\hline Significance & & $* * *$ & $* * *$ & $n s$ & $* * *$ \\
\hline \multirow[t]{4}{*}{ Plantago coronopus } & SS & $1.61 \pm 0.07 \mathrm{c}$ & $7.69 \pm 0.84 a$ & $34.19 \pm 13.34 \mathrm{a}$ & $8.35 \pm 0.96 a$ \\
\hline & $\mathrm{P}$ & $0.66 \pm 0.13 \mathrm{~d}$ & $7.87 \pm 1.20 \mathrm{a}$ & $10.03 \pm 2.91 b$ & $4.19 \pm 1.13 b c$ \\
\hline & $\mathrm{OF}$ & $1.88 \pm 0.02 b$ & $7.66 \pm 0.17 \mathrm{a}$ & $18.30 \pm 0.56 \mathrm{ab}$ & $3.11 \pm 0.74 \mathrm{c}$ \\
\hline & $\mathrm{W}$ & $2.68 \pm 0.12 \mathrm{a}$ & $4.77 \pm 0.31 b$ & $28.55 \pm 7.74 \mathrm{a}$ & $4.53 \pm 0.38 b$ \\
\hline Significance & & $* * *$ & $* *$ & $*$ & $* * *$ \\
\hline
\end{tabular}

Each value is the mean $( \pm \mathrm{SD})$ of three replicates. Means within each column, considering each species separately, keyed with a different letter are significantly different at $P=0.05$ and following, for each trace element, one-way ANOVA with the different kinds of collection (SS; P; OF; W) as variability factor. For each species in the last row, the significance level of the $F$ ratio following one-way ANOVA test is reported. $* * * P<0.001 ; * * P<$ $0.01 ; * P<0.05 ; n s:$ not significant $(P>0.05)$

examined species could be useful in the developed countries. However, common vegetables, such as legumes or spinach, as well as medicinal herbs showed a Mn content close to the species examined in this study, even though the main sources of $\mathrm{Mn}$ in the diet result commonly from the whole grains [29-31]. Iron is an essential component of some proteins as Fe-heme proteins (e.g., hemoglobin, myoglobin, catalase, and cytochromes), proteins for Fe storage and transport (i.e., transferrin, hemosiderin, lactoferrin, and ferritin), and enzymes (e.g., aconitase, fumarate, reductase, NADH dehydrogenase, succinate dehydrogenase, cyclooxygenases, and alcohol dehydrogenases) [28]. It is also required for energy production [27]. Our findings resulted similar to those reported by Turan et al. [7] in edible plants collected as wild in Eastern Anatolia. Conversely, our results resulted lower than those reported in lettuce cultivated in open field and in greenhouse by Woolley et al. [32], showing higher Fe uptake in open field growing plants and those reported by Polat et al. [33] in organically growing iceberg lettuce.

Copper is an essential element in mammalian nutrition as a component of metalloenzymes. [34]. Cu is also necessary for the development of connective tissue and nerve covering and participates in the Fe metabolism [27]. The examined species had higher $\mathrm{Cu}$ levels if compared with lettuce $[32,35]$ and lower $\mathrm{Cu}$ levels if compared with medicinal herbs such as Echinacea purpurea [36]. In our analyses, it is not possible to figure out changes in $\mathrm{Fe}$ content observed between the different cultivation techniques. In fact, according to most of our findings, Woolley et al. [32] observed the decrease of trace elements in plants domesticated in greenhouse and an increase in those domesticated in open field.

Zinc is one of the major inhibitors of copper absorption in human diet, by competing with $\mathrm{Cu}$ for transport and by increasing intestinal metallothioneins, useful proteins in detoxification and metal buffering [28]. Moreover, $\mathrm{Zn}$ in the human health is involved in the activity of numerous enzymes and deficiency of this element (recorded especially in undeveloped countries) may compromise the immune system, wound healing, senses of taste and smell, and DNA synthesis [28]. The European Food Safety Authority (EFSA) suggested that an adequate intake (AI) for $\mathrm{Zn}$ is about $10 \mathrm{mg}$ per day for a male adult, while the $\mathrm{AI}$ for $\mathrm{Cu}$ is $1.6 \mathrm{mg}$ per day [37]. The 
examined edible species reported a medium-low $\mathrm{Cu}$ content, ranging from 4.1 to $26 \%$ (per a leaf portion of $100 \mathrm{~g}$ ) of the daily AI and they had a low Zn content: 3.1 to $10.9 \%$ (per 100 g) of the Zn AI recommended by the EFSA [37]. The lower $\mathrm{Zn}$ amount suggests that this element is not available in the competition with $\mathrm{Cu}$ and the consumption of the species under investigation should be accompanied with meat or dairy products which are rich in Zn.

As reported for copper and zinc, the comparison between the AI of major minerals and trace elements suggested by the EFSA [37] and the percentage of AI may be useful to show the help that these "rediscovered" species might offer to the human diet. The wild species cannot be considered in this comparison as their commercialization would be difficult because of the inconstant growth and the scarce availability of these species into the wild. As defined by the EFSA, the AI is "the average observed daily level of intake by a population group (or groups) of apparently healthy people that is assumed to be adequate" [38]. Mineral and trace element requirements differ with age, sex, and physiological condition, due to differences in the velocity of growth for the younger age groups, and agerelated changes in nutrient absorption and body functions and/ or functional capacity, such as renal function [39]. In this study, the reported AI is related to adults and values are divided in male and female requirements (Table 4). Therefore, Table 4 reports the AI of mineral and trace elements analyzed in this study and the percentage contribution of the intake of $100 \mathrm{~g}$ of domesticated leaves to the AI of each element.

Table 4 shows that the species under investigation may contribute to the balance of major mineral and trace element intake in the human diet, overcoming micronutrient deficiencies. Among domestications, the OF itinerary appeared the most efficient domestication method for major mineral maintenance (such as $\mathrm{K}, \mathrm{Ca}, \mathrm{Mg}$ ), whereas trace element levels were generally maintained higher in $\mathrm{P}$ or SS domestications.

Trace element deficiencies are recognized as a serious global problem and since soilless systems are developed in controlled environment and substrates, in this preliminary study, P or SS domestications seem to be more efficient to alleviate trace element deficiency problems. However, further researches are necessary to confirm this aspect.

\section{Nitrate and Oxalate Content}

Nevertheless, plants may be sources of toxic compounds such as nitrate, explaining the toxic effect in nitrite, and oxalate. Table 5 reports the level of oxalate and nitrate in the analyzed species and the differences among wild and domesticated species. The highest nitrate content was found in leaves from OF domestication in all the species under investigation, while the highest oxalate level was found in leaves of the species collected as wild, except in $R$. acetosa where the significative highest oxalate content was reported again in leaves from OF domestication.

Nitrate content in vegetables is correlated to the risk factor for stomach cancer because of the nitrate ability to become nitrite in some specific conditions which, in turn, may link to hemoglobin, reducing the oxygen in human tissues, or to amines, forming cancerogenic amines named nitrosamines [40]. For these reasons, the EU Commission established maximum nitrate levels for the marketability of some vegetables such as spinach, lettuce, and rocket in the range between 2000 and $7000 \mathrm{~m} \mathrm{~kg} \mathrm{k}^{-1} \mathrm{FW}$ (Regulation No 1258/2011; https://eurlex.europa.eu/legal-content/EN/TXT/PDF/?uri=CELEX: 32011R1258\&from=GA). Leaves of the species under
Table 4 Adequate intake (AI) of each examined mineral and trace element for male and female adults and the daily percentage contribution (\%) of $100 \mathrm{~g}$ of Rumex acetosa, Picris hieracioides, Cichorium intybus, and Plantago coronopus leaves domesticated according to three different domestications: "soilless" (SS), pot (P), and open field (OF). When the value of AI was different between males and females, the daily percentage contribution was calculated on the value of males

Daily percentage contribution of $100 \mathrm{~g}$ of plant

\begin{tabular}{|c|c|c|c|c|c|c|c|c|c|c|c|c|c|c|c|}
\hline & \multirow[b]{2}{*}{ Age (years) } & \multicolumn{2}{|c|}{$\mathrm{AI}\left(\mathrm{mg}\right.$ day $\left.^{-1}\right)$} & \multicolumn{3}{|c|}{ R. acetosa } & \multicolumn{3}{|c|}{ P. hieracioides } & \multicolumn{3}{|c|}{ C. intybus } & \multicolumn{3}{|c|}{ P. coronopus } \\
\hline & & Male & Female & SS & $\mathrm{P}$ & OF & SS & $\mathrm{P}$ & OF & SS & $\mathrm{P}$ & OF & SS & $\mathrm{P}$ & OF \\
\hline $\mathrm{Na}$ & $\geq 18$ & 2000 & 2000 & 1.1 & 0.5 & 0.6 & 6.8 & 6.5 & 3.7 & 4.7 & 7.9 & 2.0 & 8.3 & 6.5 & 8.6 \\
\hline $\mathrm{K}$ & $\geq 18$ & 3500 & 3500 & 8.6 & 8.0 & 16.4 & 8.3 & 10.3 & 20.9 & 13.2 & 10.6 & 31.3 & 8.0 & 5.3 & 10.3 \\
\hline $\mathrm{Ca}$ & $\geq 25$ & 750 & 750 & 6.3 & 9.6 & 22.9 & 13.1 & 20.0 & 47.6 & 15.5 & 20.3 & 33.7 & 21.3 & 18.7 & 49.5 \\
\hline $\mathrm{Mg}$ & $\geq 18$ & 350 & 300 & 12.8 & 14.6 & 34.3 & 4.0 & 1.7 & 15.4 & 5.1 & 9.4 & 14.6 & 4.0 & 5.1 & 8.6 \\
\hline $\mathrm{Cu}$ & $\geq 25$ & 1.6 & 1.3 & 11.9 & 9.7 & 12.2 & 12.2 & 8.6 & 21.5 & 15.7 & 5.5 & 26.0 & 10.1 & 4.1 & 11.7 \\
\hline $\mathrm{Mn}$ & $\geq 18$ & 3 & 3 & 26.5 & 55.8 & 34.3 & 32.5 & 27.3 & 55.7 & 34.0 & 41.7 & 60.6 & 25.6 & 26.2 & 25.5 \\
\hline $\mathrm{Fe}$ & $\geq 18$ & 6 & 7 & 26.3 & 50.4 & 36.9 & 33.7 & 25.6 & 65.3 & 43.4 & 46.6 & 66.2 & 56.9 & 16.7 & 30.5 \\
\hline $\mathrm{Zn}$ & $\geq 18$ & 10.1 & 8.2 & 8.8 & 9.5 & 8.0 & 8.7 & 9.8 & 7.1 & 10.9 & 10.8 & 9.6 & 8.3 & 4.1 & 3.1 \\
\hline
\end{tabular}


Table 5 Nitrate and oxalate content of Rumex acetosa, Picris hieracioides, Cichorium intybus, and Plantago coronopus leaves wild collected (W) and domesticated according to three different domestications: "soilless" (SS), pot $(\mathrm{P})$, and open field (OF)

\begin{tabular}{|c|c|c|c|}
\hline \multirow[t]{2}{*}{ Species } & \multirow{2}{*}{$\begin{array}{l}\text { Wild collection } \\
\text { or cultivation } \\
\text { technique }\end{array}$} & \multicolumn{2}{|c|}{ Nitrate and oxalate $\left(\mathrm{mg} \mathrm{g}^{-1} \mathrm{FW}\right)$} \\
\hline & & $\mathrm{NO}_{3}$ & $\mathrm{C}_{2} \mathrm{O}_{4}$ \\
\hline \multirow[t]{4}{*}{ Rumex acetosa } & SS & $<0.01 \pm<0.01 b$ & $0.27 \pm 0.03 \mathrm{c}$ \\
\hline & $P$ & $0.07 \pm 0.03 \mathrm{~b}$ & $1.40 \pm 0.32 b$ \\
\hline & $\mathrm{OF}$ & $0.34 \pm 0.24 \mathrm{a}$ & $8.50 \pm 0.21 \mathrm{a}$ \\
\hline & W & $0.02 \pm 0.01 b$ & $0.38 \pm 0.14 \mathrm{c}$ \\
\hline Significance & & $*$ & $* * *$ \\
\hline \multirow[t]{4}{*}{ Picris hieracioides } & SS & $<0.01 \pm<0.01 \mathrm{c}$ & $<0.01 \pm<0.01 \mathrm{c}$ \\
\hline & $\mathrm{P}$ & $1.18 \pm 0.32 b$ & $0.05 \pm 0.04 \mathrm{~b}$ \\
\hline & $\mathrm{OF}$ & $2.58 \pm 0.24 \mathrm{a}$ & $<0.01 \pm<0.01 \mathrm{c}$ \\
\hline & $\mathrm{W}$ & $0.13 \pm 0.12 \mathrm{c}$ & $0.18 \pm 0.03 \mathrm{a}$ \\
\hline Significance & & $* * *$ & $* * *$ \\
\hline \multirow[t]{4}{*}{ Cichorium intybus } & SS & $<0.01 \pm<0.01 \mathrm{c}$ & $0.01 \pm<0.01 \mathrm{c}$ \\
\hline & $\mathrm{P}$ & $0.56 \pm 0.56 b$ & $0.14 \pm 0.02 b$ \\
\hline & OF & $3.23 \pm 0.30 \mathrm{a}$ & $<0.01 \pm<0.01 \mathrm{c}$ \\
\hline & $\mathrm{W}$ & $0.25 \pm 0.10 \mathrm{bc}$ & $0.18 \pm 0.02 \mathrm{a}$ \\
\hline Significance & & $* * *$ & $* * *$ \\
\hline \multirow[t]{4}{*}{ Plantago coronopus } & SS & $<0.01 \pm<0.01 b$ & $<0.01 \pm<0.01 b$ \\
\hline & $\mathrm{P}$ & $0.04 \pm<0.01 b$ & $<0.01 \pm<0.01 b$ \\
\hline & $\mathrm{OF}$ & $3.43 \pm 0.32 \mathrm{a}$ & $<0.01 \pm<0.01 b$ \\
\hline & $\mathrm{W}$ & $0.11 \pm 0.05 b$ & $0.11 \pm 0.01 \mathrm{a}$ \\
\hline Significance & & $* * *$ & $* * *$ \\
\hline
\end{tabular}

Each value is the mean $( \pm \mathrm{SD})$ of three replicates. Means within each column, considering each species separately, keyed with a different letter are significantly different at $P=0.05$ and following, for each anion, one-way ANOVA with the different kind of collection $(\mathrm{S} ; \mathrm{P} ; \mathrm{O} ; \mathrm{W})$ as variability factor. For each species in the last row, the significance level of the $F$ ratio following one-way ANOVA test is reported. $* * * P<0.001 ; * P<0.05$ investigation contained lower amount of nitrate than the established range and therefore are suitable for the commercialization, even though the OF domestication reported a higher nitrate content than $2000 \mathrm{mg} \mathrm{kg}^{-1} \mathrm{FW}$, but not exceeding $7000 \mathrm{mg} \mathrm{kg}^{-1} \mathrm{FW}$.

Besides, values of oxalate found in the leaves of $R$. acetosa were high, especially in OF domestication. Supportively, Yang and Loewus [41] reported values between 1.3 and $1.8 \mathrm{mg}$ oxalate $\mathrm{g}^{-1} \mathrm{FW}$ expressed as crude calcium oxalate in spinach, while the leaves of $R$. acetosa reported $8.5 \mathrm{mg}$ oxalate $\mathrm{g}^{-1} \mathrm{FW}$ in OF-grown plants. A high dietary oxalate intake stimulates secondary hyperoxaluria, a major risk factor for calcium oxalate stone formation [42]. An excessive oxalate intake also reduces the intestinal absorption of calcium and other trace elements, therefore impairing their bioavailability due to the formation of insoluble complexes [42].

\section{Conclusion}

In this study, major minerals and trace elements useful for humans of four edible plants, C. intybus, R. acetosa,
$P$. hieracioides, and $P$. coronopus (commonly used since ancient times in mixtures, boiled or in soups in the Mediterranean area), were determined in leaves once collected as wild, considering the nutritional and health roles of the analyzed minerals in the human diet. Afterwards, the preliminary investigation of an efficient domestication able to maintain mineral elements and trace elements was conducted. The main minerals $\mathrm{K}$ and $\mathrm{Ca}$ were at high level in leaves from plants domesticated in the OF, resulting sometimes higher accumulators than the wild species. Low content of trace elements was found in leaves of all species under investigation, as wild collected as well as domesticated, though $P$. hieracioides showed the highest Fe content when collected in the wild.

Finally, leaves of all the species from plants grown in the OF domestication reported the highest content of oxalate and nitrate, especially in those of $R$. acetosa. The presence of nitrate and oxalate is a negative factor in the human diet and their intake should be limited.

However, the OF domestication resulted the most promising method, maintaining the mineral content of the wild species, especially in C. intybus and $P$. hieracioides, resulting the 
most promising species for the intake of the main minerals in the human diet. Further researches are necessary to find suitable protocols of domestication aimed at decreasing the oxalate and nitrate content in the OF domestication and to make possible the commercialization of the analyzed species.

Acknowledgments Open access funding provided by Università di Pisa within the CRUI-CARE Agreement. The authors are grateful to Dr. Giulia Carmassi for useful help in the analysis of sodium, potassium, calcium, magnesium, copper, manganese, iron, and zinc.

Funding The work was co-founded by the ERBAVOLANT project (Rural Development Policy 2014-2020-Measure 16.1: Support to the Operational Groups of agricultural European Innovation Partnership (EIP-AGRI)).

\section{Compliance with Ethical Standards}

Conflict of Interest The authors declare that they have no conflict of interest.

Open Access This article is licensed under a Creative Commons Attribution 4.0 International License, which permits use, sharing, adaptation, distribution and reproduction in any medium or format, as long as you give appropriate credit to the original author(s) and the source, provide a link to the Creative Commons licence, and indicate if changes were made. The images or other third party material in this article are included in the article's Creative Commons licence, unless indicated otherwise in a credit line to the material. If material is not included in the article's Creative Commons licence and your intended use is not permitted by statutory regulation or exceeds the permitted use, you will need to obtain permission directly from the copyright holder. To view a copy of this licence, visit http://creativecommons.org/licenses/by/4.0/.

\section{References}

1. Flyman MV, Afolayan AJ (2006) The suitability of wild vegetables for alleviating human dietary deficiencies. S Afr J Bot 72(4):492497. https://doi.org/10.1016/j.sajb.2006.02.003

2. Guerrero JG, Martınez JG, Isasa MT (1998) Mineral nutrient composition of edible wild plants. J Food Compos Anal 11(4):322-328. https://doi.org/10.1006/jfca.1998.0594

3. Kennedy G, Nantel G, Shetty P (2003) The scourge of "hidden hunger": global dimensions of micronutrient deficiencies. Food Nutr Agric 32:8-16

4. Zimmermann MB, Hurrell RF (2007) Nutritional iron deficiency. The Lancet 370(9586):511-520. https://doi.org/10.1016/S01406736(07)61235-5

5. Fraga CG (2005) Relevance, essentiality and toxicity of trace elements in human health. Mol Aspects Med 26(4-5):235-244. https://doi.org/10.1016/j.mam.2005.07.013

6. Disciglio G, Tarantino A, Frabboni L, Gagliardi A, Giuliani MM, Tarantino E, Gatta G (2017) Qualitative characterisation of cultivated and wild edible plants: Mineral elements, phenols content and antioxidant capacity. Ital J Agron 12:1036. https://doi.org/10.4081/ ija.2017.1036

7. Turan M, Kordali S, Zengin H, Dursun A, Sezen Y (2003) Macro and micro mineral content of some wild edible leaves consumed in Eastern Anatolia. Acta Agr Scand B-S P 53(3):129-137. https://doi. org/10.1080/090647103100095
8. Malik J, Szakova J, Drabek O, Balik J, Kokoska L (2008) Determination of certain micro and macroelements in plant stimulants and their infusions. Food Chem 111(2):520-525. https://doi. org/10.1016/j.foodchem.2008.04.009

9. Pytlakowska K, Kita A, Janoska P, Połowniak M, Kozik V (2012) Multi-element analysis of mineral and trace elements in medicinal herbs and their infusions. Food Chem 135(2):494-501. https://doi. org/10.1016/j.foodchem.2012.05.002

10. Welch RM, Graham RD (1999) A new paradigm for world agriculture: meeting human needs: productive, sustainable, nutritious. Field Crops Res 60(1-2):1-10. https://doi.org/10.1016/S03784290(98)00129-4

11. Palaniswamy UR, Bible BB, McAvoy RJ (2004) Oxalic acid concentrations in Purslane (Portulaca oleracea L.) is altered by the stage of harvest and the nitrate to ammonium ratios in hydroponics. Sci Hortic 102(2):267-275. https://doi.org/10.1016/j.scienta.2004. 01.006

12. Tuazon-Nartea J, Savage GP (2013) Investigation of oxalate levels in sorrel plant parts and sorrel-based products. Food Nutr Sci 4: 838-843. https://doi.org/10.4236/fns.2013.48109

13. Ceccanti C, Landi M, Incrocci L, Pardossi A, Venturi F, Taglieri I, Ferroni G, Guidi L (2020) Comparison of three domestications and wild-harvested plants for nutraceutical properties and sensory profiles in five wild edible herbs: is domestication possible? Foods 9(8):1065. https://doi.org/10.3390/foods 9081065

14. D'Imperio M, Renna M, Cardinali A, Buttaro D, Serio F (2016) Calcium biofortification and bioaccessibility in soilless "baby leaf" vegetable production. Food Chem 213:149-156. https://doi.org/10. 1016/j.foodchem.2016.06.071

15. Nicola S, Hoeberechts J, Fontana E (2004) Comparison between traditional and soilless culture systems to produce rocket (Eruca sativa) with low nitrate content. ISHS 697:549-555. https://doi. org/10.17660/ActaHortic.2005.697.72

16. Guil JL, Rodríguez-Garcí I, Torija E (1997) Nutritional and toxic factors in selected wild edible plants. Plant Foods Hum Nutr 51(2): 99-107. https://doi.org/10.1023/A:1007988815888

17. Escudero NL, De Arellano ML, Fernández S, Albarracín G, Mucciarelli S (2003) Taraxacum officinale as a food source. Plant Foods Hum Nutr 58(3):1-10. https://doi.org/10.1023/B:QUAL. 0000040365.90180.b3

18. van Dronkelaar C, van Velzen A, Abdelrazek M, van der Steen A, Weijs PJ, Tieland M (2018) Minerals and sarcopenia; the role of calcium, iron, magnesium, phosphorus, potassium, selenium, sodium, and zinc on muscle mass, muscle strength, and physical performance in older adults: a systematic review. J Am Med Dir Ass 19(1):6-11. https://doi.org/10.1016/j.jamda.2017.05.026

19. World Health Organization (2012) Guideline: potassium intake for adults and children. WHO

20. Stone MS, Martyn L, Weaver CM (2016) Potassium intake, bioavailability, hypertension, and glucose control. Nutrients 8(7):444. https://doi.org/10.3390/nu8070444

21. Du S, Neiman A, Batis C, Wang H, Zhang B, Zhang J, Popkin BM (2014) Understanding the patterns and trends of sodium intake, potassium intake, and sodium to potassium ratio and their effect on hypertension in China. Am J Clin Nutr 99(2):334-343. https:// doi.org/10.3945/ajen.113.059121

22. Koudela M, Petř́ková K (2008) Nutrients content and yield in selected cultivars of leaf lettuce (Lactuca sativa L. var. crispa). Hort Sci 35(3):99-106. https://doi.org/10.17221/3/2008HORTSCI

23. Rojas-Molina I, Gutiérrez-Cortez E, Bah M, Rojas-Molina A, Ibarra-Alvarado C, Rivera-Muñoz E, del Real A, AguileraBarreiro M (2015) Characterization of calcium compounds in Opuntia ficus indica as a source of calcium for human diet. J Chem-NY 2015:1-8. https://doi.org/10.1155/2015/710328 
24. Fallovo C, Rouphael Y, Cardarelli M, Rea E, Battistelli A, Colla G (2009) Yield and quality of leafy lettuce in response to nutrient solution composition and growing season. J Food Agric Environ $7(2): 456-462$

25. Nurzyńska-Wierdak R (2009) Growth and yield of garden rocket (Eruca sativa Mill.) affected by nitrogen and potassium fertilization. Acta Sci Pol Hortorum Cultus 8(4):23-33

26. Long S, Romani AM (2014) Role of cellular magnesium in human diseases. Austin J Nutr Food Sci 2(10):1051

27. Martínez-Ballesta MC, Dominguez-Perles R, Moreno DA, Muries B, Alcaraz-López C, Bastías E, García-Viguera C, Carvajal M (2010) Minerals in plant food: effect of agricultural practices and role in human health. A review. Agron Sustain Dev 30(2):295-309. https://doi.org/10.1051/agro/2009022

28. Freeland-Graves JH, Mousa TY, Kim S (2016) International variability in diet and requirements of manganese: causes and consequences. J Trace Elem Med Biol 38:24-32. https://doi.org/10.1016/ j.jtemb.2016.05.004

29. Rebello CJ, Greenway FL, Finley JW (2014) Whole grains and pulses: a comparison of the nutritional and health benefits. J Agric Food Chem 62(29):7029-7049. https://doi.org/10.1021/ jf500932z

30. Akinyele IO, Shokunbi OS (2015) Concentrations of $\mathrm{Mn}, \mathrm{Fe}, \mathrm{Cu}$, $\mathrm{Zn}, \mathrm{Cr}, \mathrm{Cd}, \mathrm{Pb}, \mathrm{Ni}$ in selected Nigerian tubers, legumes and cereals and estimates of the adult daily intakes. Food Chem 173:702-708. https://doi.org/10.1016/j.foodchem.2014.10.098

31. Łozak A, Sołtyk K, Ostapczuk P, Fijałek Z (2002) Determination of selected trace elements in herbs and their infusions. Sci Total Environ 289(1-3):33-40. https://doi.org/10.1016/S0048-9697(01) 01015-4

32. Woolley A, Sumpter S, Lee M, Xu J, Barry S, Wang W, Rajashekar CB (2019) Accumulation of mineral nutrients and phytochemicals in lettuce and tomato grown in high tunnel and open field. Am J Plant Sci 10(1):125-138. https://doi.org/10.4236/ajps.2019.101011
33. Polat E, Demir H, Onus AN (2008) Comparison of some yield and quality criteria in organically and conventionally-grown lettuce. Afr J Biotechnol 7(9):1235-1239

34. Stern BR, Solioz M, Krewski D, Aggett P, Aw TC, Baker S, Crump K, Dourson M, Haber L, Hertzberg R, Keen C, Meek B, Rudenko L, Shoeny R, Slob W, Keen C (2007) Copper and human health: biochemistry, genetics, and strategies for modelling dose-response relationships. J Toxicol Env Health B 10(3):157-222. https://doi. org/10.1080/10937400600755911

35. Dala-Paula BM, Custódio FB, Knupp EA, Palmieri HE, Silva JBB, Glória MBA (2018) Cadmium, copper and lead levels in different cultivars of lettuce and soil from urban agriculture. Environ Pollut 242:383-389. https://doi.org/10.1016/j.envpol.2018.04.101

36. Ražić S, Onjia A, Potkonjak B (2003) Trace elements analysis of Echinacea purpurea - herbal medicinal. J Pharm Biomed Anal 33(4):845-850. https://doi.org/10.1016/S0731-7085(03)00338-8

37. EFSA (2017) Dietary reference values for nutrients. Summary Report. EFSA Support Publ 2017:e15121 98

38. EFSA Journal (2010) 8(3):1458

39. Perucca J, Bouby N, Valeix P, Bankir L (2007) Sex difference in urine concentration across differing ages, sodium intake, and level of kidney disease. Am J Physiol-Reg I 292(2):R700-R705

40. Santamaria $P(2006)$ Nitrate in vegetables: toxicity, content, intake and EC regulation. J Sci Food Agr 86(1):10-17. https://doi.org/10. 1002/jsfa.2351

41. Yang JC, Loewus FA (1975) Metabolic conversion of L-ascorbic acid to oxalic acid in oxalate-accumulating plants. Plant Physiol 56: 283-285. https://doi.org/10.1104/pp.56.2.283

42. Vasas A, Orbán-Gyapai O, Hohmann J (2015) The genus Rumex: review of traditional uses, phytochemistry and pharmacology. J Ethnopharmacol 175:198-228. https://doi.org/10.1016/j.jep.2015. 09.001

Publisher's Note Springer Nature remains neutral with regard to jurisdictional claims in published maps and institutional affiliations. 